\title{
Corruption, Transparency and the Resource Curse
}

\author{
Mingcong Li
}

\begin{abstract}
Decades ago, the common sense was that natural resource abundance was a blessing for developing countries. Yet those countries blessed with abundant natural resources seem to suffer from the so called "resource curse." In this paper we summarize the dynamics of the resource curse and review the major economic explanations for the curse: limited economic diversification, revenue volatility, and an ailment commonly known as the "Dutch Disease". We review the political explanation of the resource curse, which includes short sightedness among policymakers, poor wealth management and lack of human capital. Furthermore, we discuss whether transparency can break the resource curse and illustrate the manifestation of the resource curse in Libya, and contrasting Libya's experience with Botswana's successful wealth management then propose a number of policy recommendations for combating the resource curse, drawing from Botswana's successful policies.
\end{abstract}

Index Terms-Resource curse, economic growth, transparency, corruption

\section{INTRODUCTION}

Prior to the late 1980s, economist believes that extractable nature resources can bring prosperity and economic development. However, the experience has shown that many resource rich countries appear to have a worse performance in terms of economic development and poverty reduction than countries without such "blessings." This indicates that exporting oil and minerals by itself does not transfer from poor countries into flourishing economies. Recent studies shows the consequences of development based on the export of oil and minerals have tended to be negative during the past 40 years [1]. When compared to countries dependent on agricultural exports, the oil exporting countries suffer from unusual high poverty, high rates of civil war, corruption, low life expectancy and poor health care. All of which are surprising findings given the revenue streams of resourcerich countries. While studies have provided evidence that nature resource abundance and bad development outcomes are correlated with one another, they have not proven that the former causes the later [2]. The resource curse has not affected all countries with large oil, gas or mineral reserves. Norway and Botswana, for instance, have used their earnings to promote economic growth, address social needs and stabilize their economies. Thus, resource curse is more likely to occur when the revenue from these extractable resources is misappropriated by corrupt leaders and officials instead of being used to support economic development. Furthermore, such wealth often fuels internal grievances that cause conflict

Manuscript received June 24, 2013; revised August 25, 2013.

Mingcong Li is with the School of Arts and Sciences, University of Pennsylvania, Philadelphia, PA 19104 USA, on leave from the Beijing International Studies University, China (e-mail: mingcong07@gmail.com). and civil war. For instance, in Guinea, oil wealth has failed to generate development and has instead lead to corruption that retards growth. Teodoro Obiang Nguema Mbasogo, the president of Guinea, reported had amassed a $\$ 65$ billion personal fortune while his country ranks near the bottom on the UN's economic development scale [3]. The natural resource curse represents an obstacle to democracy and development. Although, there is no obvious ways to solve the problem, but there are certain measures that developing countries, developed countries and NGOs can all take to increase accountability and transparency.

\section{The ResourCE CURSE AND ITS CAUSE}

Resource curse refers to developing countries that have abundant extractable resources such as oil or minerals but lag behind other nations economically. The Resource curse theory was originally proposed by British economist Richard Auty, who argued in 1993 that mineral resources could distort producing countries' economies by making them prone to factors like sudden price swings and "Dutch disease," which occurs when sudden windfall profits from resource exports cause the value of a country's currency to escalate [3] .

So how can the blessing of an endowment with natural resource turn into a curse? Several explanations have been advanced from both economic and political dimension. According to the economic explanation of the resource curse, first, one common problem that contributed to the resource curse is limited economic diversification. Resource-rich countries tend to over emphasize the importance of extractable nature resource in their economy which in turn reinforces their dependence on that product [4]. Recent study shows that 80 percent of the average earnings in developing countries come from extractable commodities. Many resource-rich countries have a negative trade balance and they import more than they can export. These countries' lack of economic diversification accounts for their negative economic growth. Second, many experts argue that the resource curse place major emphasis on the failure of resource -rich developing countries to promote a competitive manufacturing sector, often refer as "Dutch Disease." This phenomenon occurs when a country depends largely on revenues from its nature resource, such as oil, gas, or mine. The inflow of wealth makes the country's currency to appreciate in value. Due to the appreciation, the country's other exports become too pricy for foreign buyers. These problems results in long-term effects on growth by reducing the country's economic diversity and increasing its dependence on nature resource export. Third, revenue volatility is another explanation for the resource curse. The basic argument is that oil, gas and mineral revenues are very 
unstable, especially driven by violent fluctuations in prices over relatively short period of time. These "frequent upward or downward adjustments of fiscal expenditures are costly" because they simultaneously discourage private investment and wreak havoc on the government's budget, thereby impeding its ability to sustain investment and public goods provision [5]. This will in turn provoke widespread breaking of contracts and erodes the rule of law. It is also negatively associated with effective investment, improved income distribution, and poverty alleviation [1].

The large revenue of resource-booms has created hardship for resource-rich developing nations. These hardships led to a persistently slow growth. Moreover, the adoption of certain policy has exacerbated the effects of the resource curse. First, inappropriate wealth management often accounts for the poor performance of resource-rich countries. This is because nature resource abundance often leads to emotional or irrational behavior on the part of political actors, especially if resources are discovered in an economy with immature institutions, the resulting rent-seeking and corruption slows down or even reverses institutional development, which in turn, negatively affects growth [6]. Boom or bust of the economy depends on how governments manage their revenues. Second, institutional weakening is probably one of the most problematic issues resulting from the resource curse. Direct access to the commodity reduces the incentives for a government to establish strong institutions. This includes, most importantly, the failure to build a tax system. Commodity booms thus encourage rent-seeking and patronage networks by removing citizen's participation in the creation of state revenues and therefore render the state decreasingly accountable to its citizens. Indeed the lack of a viable tax regime has been consistently identified with not only impeding broad economic growth but also undermining state capacity and democratization [7]. Third, the crowding out of human capital also accounts for the cause of resource curse. Resource-rich developing countries tend to neglect education since there is no immediate need for it. Development, however, is an outcome of human capabilities, because demand and price for primary products is unstable. In the long term, value of primary products rises more slowly than manufactured products. The decline of the manufacturing sector will indeed retard economic growth by decreasing both the demand for and supply of skilled labor, which in turn affects the level of income inequality and educational opportunities [5].

\section{CAn Transparency Overcome The Resource CURSE?}

A key difference between nations that flourished with natural resources and those that are "cursed" depends on the strength of government institutions before nations strike underground wealth. In many resource abundance countries, especially developing countries, little information is available about how much money the nation receives from its oil or mining operations and how that money is spent. When oil and mining companies failed to disclose payments to governments, it is easier for government officials to steal and more difficult for citizens to hold officials accountable [3].
Recognizing this problem, a coalition of anti-poverty groups such as the Open Society Institute has launched the Publish What You Pay (PWYP) campaign to call on nature resource companies to disclose all of their payments to governments in countries where they operate [3]. The establishment of such a campaign benefits citizens everywhere by reducing corruption and stimulate investment and growth. Since PWYP does not address non-traded companies or state-owned nature resource companies, the Extractive Industries Transparency Initiative (EIET) was launched at the World Summit on Sustainable Development in Johannesburg, in September 2002, to complement PWYP [3]. The Extractive Industries Transparency Initiative (EIET) proposed by British Prime Minister Toby Blair is a voluntary disclosure standard for companies and governments involved in oil, gas and mining. "Secrecy over states revenues encourages ruling elite to mismanage and misappropriate money rather than invest in long-term development" said financier and philanthropist George Soros in support of the PWYP campaign. "This is a real chance to promote good financial governance and help tackle worldwide poverty"[3]. Transparency might not be able to resolve the problem but it publicizing governments and extractive industries to deter leaders from corrupting the resource wealth.

\section{CASE Study: Libya AND The Resource CURSE}

Most economists believe that Libya is a textbook example of the resource curse. Its large oil endowment has led to form a dependency that fosters rent-seeking and corruption while preventing the development of other export sector, such as manufacturing. Libya's economy is entirely based on exporting oil to other countries. The government, however, precludes most of its population from sharing the wealth generated by resource revenue.

Oil has indirectly boosted the risk of violent conflicts through a further distortion of the national economy [8]. Gadhafi, himself, had amassed more than $\$ 200$ billion in cash, gold and investment accounts around the world when Libyans were struggling for the money they needed for education, health care and basic infrastructures. Gadhafi regime used oil profits to maintain power. Use oil profit to fund a security and military force that could silence any sign of dissent. He made Libya into a global scourge that sheltered terrorists, sponsored clandestine chemical and nuclear weapons programs and intervened in neighboring countries' civil wars. At home he presided over the Human Rights Watch called "an appalling catalogue of human rights abuses," including political arrests, torture and executions [3]. It is because of Libya's unequal distribution of wealth, its lack of transparency, diminishing opportunities for the development of human capital and corruption that led to the unavoidable revolution. Such facts lead many experts to focus on the quality of governance and wealth management policies in resource -rich countries, rather than on resource themselves.

\section{COMBATING THE RESOURCE CURSE ---BOTSWANA}

Nature resource curse is not necessarily the fate of all resource abundant countries. Botswana is one of the world's 
largest producers of diamonds, it has successfully avoided resource curse by using windfall gains to sustain economic growth. The question that then presents itself is how did Botswana escape the resource curse, ensure economic growth, and save wealth for the use by future generations? Although each countries situation is different, successful cases usually share some common elements, such as strong democratic institutions and a focus on the long term future. Since its independence in 1966, Botswana has become one of the fastest economic growing countries in Africa. Botswana's GDP grew at an average of 13.9 percent per annum between 1965-1980, at an average of 11.3 percent between 1980-1989, at an average of 4.75 percent between $1990-1998$, and at an average of 5.7 percent between 2000 -2009 (The World Bank 1991, 1998, 2001 and 2011). Many factors helped Botswana to escape the resource curse. First, during its colonial period, the country has lower levels of internal conflicts. Rich natural resources tend to exacerbate poverty and increase conflict, the impacts are especially profound in former colonies that has just gained independence. When Botswana became independent, the government focused more on education, health care and infrastructure. Later when the country realized that they are blessed with nature resources, the government demanded 50 percent of the profits and saved it for long-term needs. Besides, instead of relying only on diamond export, the Botswana government encourages diamond companies to train local cutters, creating thousands of jobs and boosting the economy. Thus the development of Botswana is not only an outcome of abundant nature resources but also of human capabilities. Second, Botswana has some strong democratic institutions which helped to prevent corruption and encourage transparency. "These attributes have enabled these leaders to withstand a culture of rampant greed that has done so much to undermine the development process in the rest of the continent," writes Hippolyte Fofack a fellow of the American Academy of Sciences in Nairobi, Kenya [9]. It is because of Botswana's wise management of its resource revenues with a focus on the long - term future and the establishment of several democratic institutions that made it one of the most successful resource-rich countries in Africa.

\section{Proposal For Solutions}

As illustrated by the Botswana case, if resource-rich countries can overcome the major challenges stated before, then they might be able to turn "curse" into "blessing" In fact, based on recent studies, some economists argue that countries with nature resource industries can become engines for economic growth, especially if nations develop these industries using advanced technologies and invest in worker training and education-what economist call human capital [10] Indeed, some poor but resource-rich developing countries, such as Botswana, have used their wealth to strengthen other sectors and promote in key industries.

As stated before, resource curse exists due to corruption, lack of rule of law, poor wealth management, and institutional weakening. In order to avoid resource curse, resource- rich countries need to balance between short term gains and long term goals, protecting the wider economy in particular manufacturing from contraction, establishing strong democratic institutions that stress transparency and ensuring inter-generational equity. Besides, the creation of PWYP that pledge government and extractive companies to disclose revenues and payments is also a good way to help to combat the resource curse.

\section{CONCLUSION}

The abundance of natural resources is after all, not the cause of poor economic growth. Rather, the extra rich resource creates incentives for poor wealth managements which in turn results in a negative growth of economy. The case of Botswana illustrates how natural resource curse is not necessary the fate of all resource-rich countries, and that good governance, transparency and a balance between short term needs and long term goals can mitigate the detrimental effects of the resource curse. However, in recent years, the lack of human capital, corruption, and the ability of governments to ignore the needs of their populations make it hard to do what it takes to resist the resource curse. In spite of experts prediction that managing resource wealth extractive industries will still continue to challenge governments in many developing countries, they also believe awareness of the resource curse is growing, and that citizens are becoming more willingly and able to hold governments accountable for resource wealth [11]. If countries learn from their past failures, they will learn that resource curse is not inevitable. Strong democratic institutions, transparency and accountability would break the corruption-resource nexus and hence create the conditions to overcome the resource curse.

\section{REFERENCES}

[1] T. L. Karl. (2005). Understanding the Resource Curse, Covering Oil: A Reporter's Guide to Energy and Development. Open Society Institute. [Online]. $\quad$ pp. 22-23. Available: http://openoil.net/wp/wp-content/uploads/2011/12/Chapter-2-readingmaterial.pdf

[2] A. Rosser, Escaping the Resource Curse, New Political Economy, vol.11, no. 4, pp. 257, December 2006.

[3] J. Weeks, The Resource Curse, Global Issues, The Congressional Quarterly, CQ Press, 2012 Edition, ch.14, pp. 359-378.

[4] P. Meijia and V. Castel, "Could Oil Shine like Diamonds?" African Development Bank, 2012. pp. 3

[5] E. Weinthal and P. J. Luong. "Combating the Resource Curse: An Alternative Solution to Managing Mineral Wealth," Perspectives on Politics, vol.4, no.1, pp. 37, March 2006.

[6] A. Durnev and S. Guriev, The Resource Curse: A Corporate Transparency Channel, CEPR Discussion Paper, 2007

[7] M. Raymond, "Explaining the Resource Curse, with Specific Reference to Mineral Exporting Countries," Resources Policy, vol. 23, no. 4, pp. 191-199, 1997.

[8] F. Carmignani. (October 2011). After Gaddafi, will Libya's 'Resource Curse' become a Blessing? [Online]. Available: http://theconversation.com/after-gaddafi-will-libyas-resource-curse-be come-a-blessing-3410

[9] M. Sarraf and M. Jiwanji, "Beating the Resource Curse - The case of Botswana," presented at the Environment Department, World Bank, Washington DC, October 2001

[10] N. Shaxson. "Oil, Corruption and the Resource Curse," Blackwell Publishing Ltd/The Royal Institute of International Affairs, vol. 83, no. 6, pp. 1123-1125, 2007

[11] S. Bryan and B. Hofmann, Transparency and Accountability in Africa's Extractive Industries: The Role of the Legislature, National Democratic Institute for International Affairs, Washington DC, 2007, pp. 26 


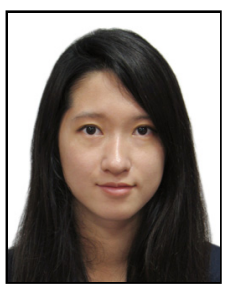

Mingcong Li was born on March 9, 1992 in Jilin, China, she is a senior at the Beijing International Studies University (BISU) pursuing a bachelor's degree in Law. Her coursework focuses mainly on the substantial area of International Law. She studied abroad at the University of Pennsylvania in the academic year 2012-2013. During her study at the University of Pennsylvania she has completed a variety of coursework in different fields, including International Relations, International Law, Sociology and Economics, which further developed her interest in international affairs and specifically U.S. foreign policy in East Asia.
In the summer 2013, she worked as a research intern at the Think Tank and Civil Societies Program (TTCSP) at the University of Pennsylvania, Philadelphia. Her obligations include collecting and updating information resource on think tanks in the Global Directory of Think Tanks and conducting research and survey on think tanks in Asia and their efforts to influence world governance. Her work through this program helped to generate the 2013 Annual Global Go To Think Tank Rankings (GGTTTR), which is the most authoritative source for the leading public policy research organizations in the world. Having spent a substantial years of her childhood in Europe and China, her interests gravitate toward international relations. She hopes to further explore and research on security issues related to the future of Sino-American relations and East Asia. 